Journal of Critical Race Inquiry

Vol. 2, No. 2 (2015) pp. 25-53

\title{
Racial Diversity Deficit in College Football: Fixing the Pipeline
}

\author{
Keali'i Troy Kukahiko \\ Department of Education, University of California, Los Angeles
}

\begin{abstract}
A growing amount of research is being conducted on racial diversity in college football head coaching positions in the United States. However, very little has been conducted on the entry-level positions in college coaching: Graduate Assistants (GAs), Quality Control assistants (QCs) and restricted earnings coaches. These positions represent natural professional trajectories for student-athletes, who constitute the future pool of applicants for college coaching positions. In the United States, the majority of student athletes are nonwhite, but white coaches still dominate the world of college athletics. This paper investigates the pipeline issues that obstruct the matriculation of nonwhite student-athletes and produce what I call the diversity deficit in college football coaching. Existing analyses of empirical data from member institutions of the National Collegiate Athletic Association (NCAA) demonstrate the existence of racial inequality in the profession of coaching. This paper will explain the perpetuation of the diversity deficit by employing Critical Race Theory (CRT) to illustrate how whiteness, color-blindness and tokenism structure college football coaching. The paper then presents new research data that illuminate how power shapes NCAA member institutions and that can aid participants in addressing pipeline issues and the diversity deficit.
\end{abstract}

Keywords : Race, Diversity, Football, Campus Climate 


\section{Introduction}

A growing amount of research is being conducted on racial diversity in college football head coaching positions in the United States. However, very little has been conducted on the entrylevel positions in college coaching: Graduate Assistants (GAs), Quality Control assistants (QCs) and restricted earnings coaches. These positions represent natural professional trajectories for student-athletes, who constitute the future pool of applicants for college coaching positions. In the United States, the majority of student athletes are nonwhite, but white coaches still dominate the world of college athletics. This research investigates the pipeline issues that obstruct the matriculation of nonwhite student-athletes and produce what I call the diversity deficit in college football coaching. Existing analyses of empirical data from member institutions of the National Collegiate Athletic Association (NCAA) demonstrate the existence of racial inequality in the profession of coaching. This paper will explain the perpetuation of the diversity deficit by employing Critical Race Theory (CRT) to illustrate how whiteness, color-blindness and tokenism structure college football coaching. The paper then presents new research data that illuminate how power shapes NCAA member institutions and that can aid participants in addressing pipeline issues and the diversity deficit.

College football has established itself as a major contributor to the institutional prestige and revenue of institutions of higher education (Anderson, 2012). Within the profession of college football coaching, white people historically have held exclusionary rights to the hiring of head coaching positions and, subsequently, of all subordinate levels of college coaches. A growing amount of research is being conducted on the diversity of head coaches in college football (Singer, Harrison, \& Buckstein, 2010; Pike, 2011). Yet existing research tends to account for the diversity of coaches in college football from the top down, by focusing on the head coaching position. The major policy impact of such research has been the establishment of affirmative action programs that seek to mandate interviews of nonwhite candidates for head coaching positions. However, interview mandates have created a turnstile for a short list of nonwhite college coaches (27 candidates in 2012) who often are called in for pro-forma interviews by organizations that only intend to score well on "diversity report cards" (Gaither, 2012). Affirmative action policies in college football coaching take a top-down approach that only addresses access at the head coaching level. Such policies ignore pipeline issues: namely, the need to develop and mentor nonwhite coaching assistants who can contribute to the future applicant pool. Given that over half of football student-athletes in the United States are of color, how can hopeful candidates become full-time college football coaches? Researchers need to examine the GA and QC positions to better understand pipeline issues that restrict or enable access for minorities into college football coaching. 
The following research questions guide this study:

1) What are the experiences of GAs and QCs of color, and how are their entrylevel roles and positions interpreted within the professional pipeline of college coaching?

2) What do administrators, staff, full-time college coaches, GAs, QCs and restricted earnings coaches believe is limiting the ability for coaches of color (in entry-level positions) to be promoted to full-time staff positions?

Citing the experiences of people who work in the GA, QC and restricted earnings positions, this paper examines their varied levels of perception of the importance of racism, stereotyping or tokenism in shaping the coaching profession, and offers suggestions for making entry-level positions points of access for the advancement of coaches of color.

\section{Background}

Within the NCAA, football coaching is organized hierarchally around the head coach, who bears responsibility for the entire operation and delegates responsibility across numerous subordinate positions. Under the head coach are nine full-time coaching positions with salaries that vary depending on the financial strength of the athletic program. These coaches are responsible for the recruitment and core position development of the players. Two such coaching roles are the Offensive and Defensive coordinators, which manage the team's offensive/defensive strategies and performance and supervise the offensive/defensive position coaches. The position coaches are generally responsible for developing and recruiting position-specific players and responsibilities. NCAA Division I college football programs are limited to ten full-time coaching positions and four graduate assistant (GA) positions. The limitations are set to maintain a level playing field, so that lower-revenue programs can maintain a competitive status with programs that otherwise could hire more resources. The staff, or administrative support positions include Player Development, Football Operations, Football Relations, Player Personnel and Recruiting Coordinator positions. Other actors include sponsors, alumni and support personnel (e.g., trainers and academic support). My research examined issues that restrict or enable the diversification of college football coaches by reviewing the head coach, full-time coaches, staff/administrative support positions, athletic directors, and the QC, GA and Restricted Earning positions. These positions occupy the football offices at NCAA member universities and are responsible for recruiting and coaching student-athletes. They represent the pipeline.

Football players and football enthusiasts long have sought entry into college coaching. These dreamers vary in their years and levels of experience, but most come with hopes of 
coaching at a four-year university. A rite of passage for a majority of these hopeful applicants has become the de facto prerequisite of becoming a GA (Levesque, 2009), a QC (Birkett, 2010) or a restricted earnings coach. Assuming one of these roles has become a hiring standard that precedes promotion to full-time coaching positions. GAs are similar to studentathletes, in that they receive athletic aid for academic programs and receive stipends for living expenses (Daughters, 2012). Their work often is exhausting, with a workload sometimes accruing 100 hours a week (Leonard, 2012). Individuals are limited by the NCAA to three years of participation in the GA program. In August of 2012, the NCAA increased the number of GAs permitted per college football program from two to four, in an attempt to increase the number of minority coaches (FootballScoop, 2012) as I discuss below.

The Quality Control (QC) position plays de jure and de facto roles in college football. The job description for QCs often includes video editing, statistical and video analyses and administrative paperwork. The NCAA has not regulated the numbers of these positions. In practice, the QC has been predominantly a coaching role, and the position has been used by a number of programs to "pack" as many coaches into the organization as possible. Perhaps in an attempt to untangle itself from the regulatory process of this position, the NCAA has deregulated the recruiting roles this position held in the past. This policy change now allows the QC to participate in the recruiting of high school and junior college student-athletes. This change has the potential to create a pipeline for nonwhites aspiring to become legitimate staff members of college football programs.

The restricted earnings coaches are similar to a GA, but they are not responsible for graduate coursework. They have the same coaching responsibilities as a GA, and they receive pay similar to the financial aid afforded to GAs. At present, the earnings of these types of coaches are limited to $\$ 12,000$ during the academic year and $\$ 4,000$ during the summer months, (CBS, 1999). Coach 13, a participant in this study who is a nonwhite full-time coach at a Division I-A football program, reported that "restricted earnings coaches are full-time coaches that get paid less, about the same as GAs, and like QCs are only limited by the budget of the football program." The NCAA was sued for antitrust violations by restricted earnings coaches from multiple sports within its membership institutions, which the NCAA settled in mediation for \$54.5 million in 1999 (CBS, 1999). Now, restricted earnings coaches are used only in the Football Championship Subdivision (Division I-AA) and count towards the cap of ten coaches per team. 


\section{Literature Review: Explaining the Diversity Deficit}

The diversity deficit in college football is evident in the significant gap between the percentage of student-athletes of color and that of coaches of color. According to the NCAA, as of March 2010, 11 percent of head football coaches at Division I-A schools were nonwhite (Pike, 2011) contrasted with the 55 percent of nonwhite student-athletes who compete in these top programs. At the NCAA Division I-AA level -- and excluding historically black colleges and universities -- 7 percent of head coaches were of color. In 2012, at both the DI-A and DI-AA levels, coaches of color accounted for 16 percent of the offensive and defensive coordinator positions, and 23 percent of the assistant coach positions (Lapchick, 2012). These numbers suggest a pipeline issue, given that nonwhite coordinators (16 percent) and assistant coaches (23 percent) fall significantly short of the percentage of nonwhite student-athletes (55 percent).

While the NCAA allows institutional autonomy in the governance of hiring policies in its member universities, several affirmative action agendas have surfaced in an effort to close the gap between the number of white head coaches and head coaches of color. The Black Coaches and Administrators (BCA) organization developed a Football Hiring Report Card (HRC) that grades organizations on their inclusion of nonwhite candidates in their interview processes for head coaching positions in college football (Harrison, Lapchick and Jansen, 2009; Singer, Harrison, \& Buckstein, 2010). Programs identified as having advertised head coaching positions are given letter grades from A-F based on five criteria: 1) Communication; 2) Hiring/Search Committee; 3) Candidates Interviewed; 4) Reasonable Time Frame; and 5) Affirmative Action. Singer, Harrison and Bukstein (2010) offer an important critical race analysis of these five aspects of the hiring process of college football head coaches. The same critical framework also could be applied to the entry-level position pipeline and the matriculation of nonwhite coaches within college coaching.

Gaither (2012) reports that thirty-nine head coaching positions came available during the 2010-2011 season. In 2011 the HRC assigned to Football Bowl Series (FBS) and Football Championship Series (FCS) schools twenty-one A grades, seven Bs, seven Cs, one D and three Fs. The data suggests that the HRC has had a significant impact: Lapchick (2012) reported a 61 percent increase in all coaches of color hired since the first HRC in 2004, with 54 percent of all coaches of color in the history of college football having been hired in the last three years of the study. The 2003 to 2012 seasons saw a 600 percent increase in FBS head coaches of color (from three to eighteen). However, in 2012, college football was the only collegiate sport to increase its percentage of white head coaches and to decrease the total 
number of nonwhite coaches. Lapchick examines this disparity by addressing what I refer to as the white hegemony in college athletics:

The fact is that 90 percent of our [college or university] presidents are white, 87.5 percent of our athletics directors are white, and 100 percent of our conference commissioners are white. In those positions, 76, 84.2, and 100 percent are white men, respectively. Overall, whites hold 332 (90.7 percent) of the 366 campus leadership positions reported in this study, which is no change in quantity from last year although the percentage dropped due to an increase of reportable leadership positions. The stagnant nature of diversity in campus leadership does not reflect the America that we know. (Lapchick 2012: 1)

Lapchick also notes that the Faculty Athletics Representative (FAR), a position that is responsible for student-athletes' transition, retention and social welfare, was 94.4 percent white in the Football Bowl Series division, and that 79 percent of faculty in that division were white. Furthermore, in the 2011-12 season -- before the NCAA increased the number of GAs from two to four -- 219 out of 302, or 73 percent of GAs were white (NCAA, 2012).

What do these data mean for the future applicant pool of college coaches? Will the recent increase in the number of GAs improve opportunities for nonwhite college coaches, or will it simply double the number of white coaches and escalate the diversity deficit? The demographic information on GAs is currently unavailable on the NCAA website, and no statistics are available on QC or restricted earnings positions. The demographic information the NCAA is willing to share remains a moving target.

I argue that the diversity deficit is perpetuated in college football by a white hegemony and its a dominant narrative: that we exist in a post-racial era in which race does not matter and meritocracy is a virtuous mechanism of social selection. The next section introduces Critical Race Theory (CRT) as a framework for critically evaluating this dominant narrative and its myths of meritocracy and individualism. I also examine the dominant narrative with respect to whiteness and color-blindness, tokenism, and the question of whether the Contact Hypothesis or Class Conflict Theory are appropriate models for affirmative action efforts in the hiring of college football coaches. Taken together, these theories provide frameworks for identifying structures and mechanisms that perpetuate the diversity deficit, such as the denial of racism, and for considering and evaluating solutions to the diversity deficit in college football. 


\section{Critical Race Theory}

The histories of slavery, colonization, economic imperialism and militarization have given dominant racial groups a head start in the accumulation of wealth and have segregated U.S. society by race and class. These histories of oppression resulted in nontraditional pathways to higher education for many people of color, such as through military service and college athletics. Within college football, the pipeline of student-athletes to college coaching positions should be reinforced to transition and retain student-athletes of color. Visualizing this pipeline offers student-athletes of color physical and psychological support for imagining and pursuing their place in higher education. The causal relationships between histories of oppression and the academic and professional trajectories of student-athletes of color can best be framed and understood through the application of Critical Race Theory (CRT). Among the many CRT scholars who make invaluable contributions to the literature, Kohli and Solorzano (2012) suggest five tenets of CRT that provide appropriate guidelines for this research: 1) Centrality of Race and Racism; 2) Challenging the Dominant Perspective; 3) Commitment to Social Justice; 4) Valuing Experiential Knowledge; and 5) Being Interdisciplinary. I will highlight the relevance of all five tenets in considering the diversity deficit among college football coaches.

Centrality of race and racism. This tenet recognizes that race remains central and relevant, and that racism is endemic in U.S. society. The tenet allows this research to provide historical context for empirical data without apologizing for racial disparities that are obvious and apparent. A racial chasm exists between the current ratio of college football coaches of color at $25 \%$, to college football players of color at $55 \%$, and the ratio of white college football coaches at 75\%, to white college football players at 45\% (NCAA, 2012). The same histories of structural oppression that created adverse consequences for communities of color in the United States also granted whites the power to define rules for admission at elite universities where the diversity deficit in college football exists. Racism is a contemporary and everyday occurrence that perpetuates inequity between the dominant racial group and people of color.

Challenging the dominant perspective. The current dominant perspective is one of color blindness: it ignores that whites have privilege, maintaining that racism and discrimination no longer exist (Ullucci \& Battey, 2011). This dominant perspective has been only mildly challenged by affirmative action efforts, which embrace the idea that the inclusion of nonwhite candidates in the interview process will result in more nonwhite head football coaches, or that increasing the number of GAs and QCs (without requiring that any be of 
color) will increase the pool of nonwhite candidates. College football governing organizations have acquiesced to affirmative action efforts as a benign and diplomatic concession. Yet such efforts burden social justice advocates with the work of bargaining for equitable hiring practices. The dominant perspective is quick to applaud the impact of affirmative action efforts, but a slight shift in numbers does not constitute a paradigm shift, nor does it reflect "fundamental improvements in traditional practices and approaches" (Chang, 2002, p. 131) or what Smith et al. (1997) calls "institutional transformation." This research is designed to further illuminate the white dominant narrative within college football coaching and to challenge it by re-centering the marginalized voices of nonwhite college football coaches.

Commitment to social justice. Without a commitment to social justice, parties that influence and benefit from the financial success of college football will simply pay "lipservice" to diversity efforts. The transference of knowledge about the diversity deficit is critical to creating empathy. Ladson-Billings (2006) defined moral debt as the disparity between what we know to be right and what we actually do. Building from this claim, only social justice will repay our moral debt to coaches of color in college football. While in 2012, the NCAA increased the permitted number of GAs from two to four, some football programs (like the primary site of my study) have filled all such positions with white candidates, thereby nullifying the policy intent of racial diversification (FootballScoop, 2012). Without a commitment to social justice, college football and its constituents will never realize the full benefits of diversity among college football staff members, student-athletes, the general student body, the community at large or the institution of higher education. This research was implemented so that social justice agents can refer to it when creating policy solutions that will decrease the diversity deficit in college football.

Valuing experiential knowledge. Looking past the guidelines and hiring rules that establish what is allowed within college football by the NCAA, this research used interviews and surveys to gather information from coaches, players, staff and administrators who occupy different levels within football organizations. Their narratives are important because their perceptions of reality produce the reality of college football. Job descriptions, employee handbooks, rules, regulations and hiring standards mean nothing if they are not followed. The only way to uncover what is perceived to be the reality of college football is to record the narratives and counter-narratives of participants. Counter-narratives attempt to problematize concepts that are considered to be common sense, and help recalibrate ideas of right / wrong or truth / libel based on experiential knowledge. We cannot hope to achieve an objective 
account of college football coaching without considering all perspectives, and most especially those of marginalized participants.

Being interdisciplinary. History, sociology, psychology, law, education, economics, gender and ethnic studies are just some of the disciplines that have contributed to the scholarly literature on diversity. The multi-disciplinary and interdisciplinary approaches among these fields provide frameworks for identifying the existence of racism and its modifications within power structures and social processes. Within this research, examining history allows us to see how specific groups that participate in college football have been excluded from higher education. The study of law helps us understand what processes and structures formed to maintain this exclusion, and how they are reinvented so that they persist in today's putatively post-racial and colorblind society. Psychology helps us to understand the impact of exclusion on the well-being of nonwhite participants, while sociology suggests how this exclusion might impact our social behavior within communities, organizations or institutions. Within the discipline of education we can examine what is required to increase participation in higher education among historically-excluded communities of color. Doing so may pay our country's moral debt: not simply to include nonwhite groups within the current education system, but also to allow their histories, cultures and ways of knowing to recreate that system. This research draws from literatures within and interlinking these and more disciplines to understand root problems and to consider diverse solutions to correcting the diversity deficit in college football.

\section{Whiteness and Colorblindness}

Ullucci and Battey (2011), citing the work of Gillborn (2009) define whiteness as having three objectives, which include three "key components": 1) "downplaying" white privilege and being unwilling "to name the contours of racism"; 2) avoiding "identifying with a racial experience or group (making Whiteness 'normal' and ethnically identified groups 'other')"; 3) minimizing racist legacies by "seeking to place racism in a historical, rather than contemporary context" (Ullucci \& Battey, 2011, p. 1199). Colorblindness is a concept that has been championed by the dominant culture. Colorblindness asserts that merit and individualism are objective criteria for professional assessment, and that the Civil Rights Movement of the 1960's catapulted U.S. society into a post-racial era where race no longer matters. Examining whiteness and colorblindness within college football will reveal how these components act together to produce and reproduce racism. Even if color-blind racism is not overt, loud, angry or a violent demonstration of discrimination, it still perpetuates the same 
outcome: a "White-topped racial hierarchy" that maintains the hegemonic status quo (Ullucci \& Battey, 2011, p. 1204). This is exemplified by the predominantly white search and hiring committees that hire college head football coaches (Singer, Harrison \& Bukstein, 2010).

The dominant narrative maintains that meritocracy is the mechanism of social selection. This common sense paradigm within college football is a form of colorblindness: it argues that by solely considering merit and individual experience, the best candidate will get the job regardless of race. However, in the U.S., the perspective that merit and individual experience exist independently of race, class, gender or other privileges exclusively defines the cultural experience of white groups (Ullucci \& Battey, 2011). The colorblind view of merit or individual experience in the hiring process ignores the socio-historical factors that influence them. For example, access to relationships that influence the hiring process -- hiring trees (Harrison \& Yee, 2009; Brooks, 2002), which are examined below as "good 'ol boy networks" -- are a type of social capital that is traditionally enjoyed by white coaches. A colorblind lens ignores the history of institutional racism that has excluded nonwhites from college athletics as student-athletes and as coaches (Singer, Harrison \& Bukstein, 2010). White privilege has given white coaches near-exclusive access to the professional experiences that are required of head coaches by hiring committees. Colorblindness ignores the trickledown effect of these processes on the perpetuation of a white hegemony within college football coaching, at administrative and faculty levels. It also ignores how whiteness affects campus climate and the sense of belonging and well-being among people of color within institutions of higher education.

Colorblindness imagines a racially assimilated society in which race is irrelevant. Yet Ullucci and Battey (2011) state:

While a "raceless" society may be sold as utopian, such a society requires the obliteration of cultural differences. The end product would surely not be a society based on African American norms or Latino cultural norms. (p. 10)

The inaction of NCAA member universities to correct the diversity deficit in their athletic departments is an act of neutrality that is neither innocuous nor innocent. This neutrality is unmoved by an obvious diversity deficit between student-athletes and the coaches that recruit and manage them. This neutrality is undaunted by the racial microaggressions (Solorzano, 1998; Solorzano, Ceja, \& Yosso, 2000) that people of color have endured in college athletics, and the harmful effects that racism-related stress (Crocker, 2007; Reynolds, Sneva \& Beehler, 2010) has on the members of their institutions. This neutrality fails to recognize that neutrality is racism. 
Ullucci and Battey's (2011) framework should be used to challenge members of the NCAA in four specific ways:

1) Challenge the whiteness of Hiring Search Committees for head football coaches;

2) Validate the experiences and perspectives of college football coaches of color, and understand how these factors affect merit and individual criteria in the hiring process;

3) Name racist hiring practices, and develop race-conscious hiring policies;

4) Challenge neutrality in NCAA member university policies and identify institutional racism.

\section{Tokenism and Symbolic Boundaries}

Nonwhite college coaches who work in environments dominated by whiteness and colorblindness often are pigeonholed into certain types of coaching positions that are considered appropriate for minorities. Lower level coaches of color often are given less mission-critical responsibilities, and more relational player personnel roles. In this hiring context, tokenism has become a popular method for the use of nonwhite coaches to recruit nonwhite student-athletes. The organizational outcome of physical diversity without psychological, social, cultural and financial validation is tokenism. Hurtado et al. (1998) state that tokenism can contribute to the hyper-visibility of underrepresented groups, an exaggeration of group differences, and the distortion of images and situations to fit existing stereotypes.

To understand tokenism in college football, we can consider the coaches of color who occupy non full-time or entry-level positions. Many of these nonwhite coaches are hired onto football programs to help recruit and retain nonwhite student-athletes. In this study, Coach 11 stated, "More often than not minorities are hired merely for the fact that most kids that play the game of football are minorities, so it is used as a selling point to recruits and their families." Symptoms of tokenism are apparent when predominantly white coaching staffs hire nonwhite coaches without meaningful roles and without salaries that are commensurate with those of their peers. GAs, QCs and restricted earnings positions in these types of environments make the exploitation of brown bodies more obvious. In college football programs where tokenism exists, the true benefit of racial diversity is lost.

In this type of environment, the diversity deficit also can be affecting the pipeline of student-athletes into the profession of college coaching. Nonwhite student-athletes may perceive that college coaching is not a realistic professional goal if cues indicate to them that only whites can become college football coaches, or that nonwhite coaches are tokenized. Prudence Carter (2012) called these cues "symbolic boundaries." Student-athletes may be 
dissuaded from pursuing this profession if cues or boundaries indicate to them that only white heterosexual men become college football coaches, that only white coaches occupy positions with meaningful roles, or that nonwhite college coaches do not receive the same financial reward as their white counterparts. Given the media coverage of college football games, perhaps we also must be concerned that these symbolic boundaries are being conveyed not only among student-athletes but also to the national and international community.

\section{Contact Hypothesis and Class Conflict Theory}

Within social-scientific theories of conflict and prejudice, the contact hypothesis suggests that positive contacts between in-groups and out-groups will reduce prejudice. However, Nkomo (1992) criticizes this theory by arguing that it underscores the need to structure social environments around cooperation rather than competition. With respect to college football, the contact hypothesis would suggest that players and lower-level coaches of color, on the one hand, and white players and coaches on the other will come to understand and accept each other by interacting, and that racism subsequently will disappear. However, within college football, the power dynamics between those who produce the labor and those who manage it remain racialized and perpetuate racism. Organizations have looked to correct the diversity deficit by creating affirmative action policies that focus on creating contact during interviews for head coaching positions. However, these policies only mandate that coaches of color be included in the hiring process, not that they actually be hired.

One such national diversity effort is the Oregon State Legislature's implementation of the NFL's Rooney Rule. Named after Dan Rooney, the Pittsburg Steelers owner who also was the chairman of the NFL's diversity committee, the Rooney Rule mandates minority interviews for every available head coaching position in the NFL. The initiative for a college version of the Rooney Rule has been called the Robinson Rule, named after the legendary Eddie Robinson who coached at Grambling State University for 55 years and became the most winning coach in college football history. The Oregon Legislature enacted the Robinson Rule into law, mandating that Oregon college football programs must interview minority candidates for all college head coaching positions (Pike, 2011). Nigel Burton was hired as the head coach of Portland State University the same year that the Oregon State Legislature enacted the Robinson Rule. Unfortunately, in January of 2013, eight NFL head coaches were hired, but none were coaches of color despite the availability of qualified minority candidates (Hanzus, 2013).

Affirmative action initiatives to integrate coaches of color into the interview process

have created a turnstile for a short list of minority candidates (27 qualified minority candidates, in 2012) who are called in for pro-forma or "token" interviews by organizations 
that only intend to score well on diversity report cards (Singer, Harrison \& Bukstein, 2010; Gaither, 2012). These policies, however, take a top down approach that only addresses access at the head coaching level. They ignore pipeline issues that deal with the development and mentorship of nonwhites in entry-level positions. Considering that over half of football student-athletes are persons of color, clearly a significant applicant pool is available.

Nkomo (1992) points out that power conflict theories identify causal relationships between the rise of capitalism and nationalism, and the rise of racial exploitation and racial prejudice. This concept could be supplanted by the idea that racial exploitation and race prejudice in college football began with the rise of academic capitalism: the trend of neoliberalism in higher education and in the maintenance of institutional prestige. These forces have transformed student-athletes into sites of profit, and brown bodies into natural resources. In light of this reading, NCAA member institutions must collectively address their duality: they cannot serve their mission statements of diversity and democratization while submitting to the demands of athletic neoliberalism in college football. No longer can they continue their "laissez-faire approach to diversity" (Hurtado, Milem, Pedersen, \& Allen, 1998, p. 279) If Nkomo (1992) is correct in her critique of the contact hypothesis, diversity initiatives in college football may continue on their leisurely path and maintain the diversity deficit.

\section{Methodology}

The aforementioned theoretical frameworks provide the basis for this project's research methodology. CRT directs this project to center marginalized voices, to use narratives and lived experiences to contextualize quantitative data and to provide a counter-narrative to the dominant discourse on diversity in higher education. These methodological strategies intend to reach beyond cursory survey responses and to ask participants what different perspectives mean to them. This methodology places meaning- making in the domain of the participants, not the researcher.

The study incorporates the narratives of seventeen football coaches who were navigating, or who have navigated the pipeline to coaching college football. The narratives were collected in 2014. Western University, the pseudonym for my primary site of research, is a public institution of higher education with a football program within the Football Bowl Subdivision (FBS). The 2013 football team boasted a diverse coaching staff (44\% of the fulltime coaches were nonwhite): three of four QCs were nonwhite, and one of four staff members were nonwhite, but all four GAs were white. While $47 \%$ of the total football staff was nonwhite, nonwhite student-athletes still made up $72 \%$ of the football roster. $72 \%$ of the 
general student body was nonwhite as well, but only $3.8 \%$ were Black; in contrast to the football team, where Blacks represented $55 \%$ of the entire team roster.

I attended practices and games, observed office activity and team meetings at Western University, as well as many college football programs across the country. On my first official site visit to Western University's football program, I took fieldnotes with my iPad and had the opportunity to informally interview one staff member. During my observation, I was able to identify the racial diversity of coaches (GAs, QCs and staff) and to supplement my online research of the racial make-up of the football players on this particular team. I also was able to observe the roles and responsibilities of these different coaching and administrative positions. During my interaction, I identified three of my seventeen research participants from this athletic staff, and after explaining my research agenda, they were willing to share their narratives with me.

In addition to the data gathered at Western University, I identified fourteen other participants from college football programs across the U.S. In all, I interviewed fourteen coaches (full-time, GAs, QCs and restricted earnings), two staff/administrative support positions and one athletic director. Six of these participants were white, including three head coaches, two coordinators and one director of football operations. The remaining eleven nonwhite coaches included two coordinators, two full-time coaches, three QCs, one GA, one restricted earnings coach, one Player Personel staff member and one athletic director/adminsitrator. Of the total participants, six had once been a QC or Restricted Earnings coach. I took notes, because video or audio taping would have been too intrusive and threatening for the casual tone of conversation I planned to have with them.

Research participants were selected because they once had been GAs, QCs, restricted earnings coaches, or had matriculated to full time staff/athletic administrators. These participants are people with whom I have had varying degrees of contact during my work with student-athletes. I have attended practices and games and I have observed office activity and team meetings at many college football programs across the United States, in my capacity as a strength/conditioning, speed/agility and football coach. Each participant was asked to respond to three specific prompts: (1) What is hindering the development of coaches of color to fulltime coaching positions? (2) Is the GA or QC position an appropriate mechanism for creating a to full-time positions? (3) Describe your coaching experience, position and racial identity. The responses to those questions were coded and I provide an analyses of those narratives in the Findings section.

In addition to gathering these seventeen narratives, I also surveyed forty high school student-athletes at a Westen University Pacific Islander Student Association (PISA) outreach 
conference in 2013 about the importance of diversity in their college choice. This survey was adminstered to the participants after a workshop on stereotypes. These forty student-athletes were asked five open-ended questions about the importance of physical diversity (racial representation) on the college coaching staff: 1) Was it important to their college choice if the head coach was of color, or same race/ethnicity? 2) Was it important that their position coach was of color, or same race/ethnicity? 3) Would this impact their college choice? 4) If so, why? 5) What was the most important thing in deciding their college choice?

From this original construct I then developed a more comprehensive survey and administered this to seventy high school football players at the 2014 AIGA Foundation's Polynesian All American All Star game. The revised survey asked student-athletes to address the effect of diversity within college coaching positions on their college choice, their perception of their place in higher education, and their potential matriculation into the coaching pipeline by ranking the level of importance of these concerns on a scale from 1-5. I then identified twenty of these high school All Stars as student-athletes who were being recruited actively by college football programs with scholarship offers. These respondents were asked to respond to questions regarding diversity and the impact of diversity on their college choice, to share written accounts of their experience and to participate in focus groups of 2-5 people for thirty minutes in a private room. They had prior knowledge of the topics of the focus groups, which had been introduced in the preliminary survey so that they would be familiar with the questions. These surveys provided additional information on the importance of coaches of color to the recruitment of student-athletes of color, to their sense of belonging, and ultimately to their college choice.

\section{Positionality}

It is critical that scholars recognize the inherent bias of researchers who investigate social issues around communities of color in the U.S. That is why my positionality statement is fundamentally imperative here. As Kanaka Maoli (indigenous people of Hawai'i) our names are important because they reflect our epistemology handed down by our kupuna (ancestors) through mo'olelo (stories). These mo'olelo contain not only our history and the information to maintain our culture and epistemology, but also our kupuna's hopes for the future of lahui (the Hawaiian nation). It is important that those who read my research to understand that my identity as a member of the lahui frames my analyses of contemporary issues that impact communities of color in the US.

I have trained and mentored hundreds of student-athletes and placed them into college athletic programs all around the world. Throughout this process I have experienced the 
opportunities that athletics provide in creating nontraditional pathways to education. I have also seen the exploitation that has occurred as a result of neoliberalism in college sports, which emphasizes the student-athletes as profit-centers and deemphasizes their roles as students in the academy. I believe that the histories of slavery, colonization, economic imperialism and militarization (specifically in the Pacific) have hindered access to higher education in communities of color, especially where economic specialization supports industries that nullify the utility of college degrees. These forces have created nontraditional pathways to higher education for these communities through military service and college athletics. To transition and retain student-athletes of color, the pipeline of these studentathletes to college coaching positions should be reinforced. This pipeline is a visual representation of their place in higher education, and provides physical and psychological support to student-athletes of color.

\section{Findings}

\section{High School Recruits}

Using interviews and surveys of forty high school football recruits at one event, I found that $78 \%$ responded affirmatively that having a coach of color was an important factor in choosing a collegiate program. That is, thirty-one of the forty athletes surveyed at one event answered that it was important that there be at least one coach of color at the college they choose to attend. One important finding was that none of the recruits thought race was the most important factor in either their position coach or the head coach. Simply the presence of diversity somewhere on the coaching staff was of importance to these students. Of those that believed diversity was important, most said that they believed having a coach that represented their ethnicity would make them feel more comfortable. Others thought it meant that they would have someone that understood them, and some thought that it would eliminate the possibility of being "the only one." Eight respondents thought it was important but not necessary, and only one high school football recruit thought that diversity was unimportant. Notably, of the twenty top recruits that were interviewed, 95\% said they would not commit to a football program that did not have a coach of color. It should be noted, however, that this event was hosted by a Polynesian community organization, and that all but one of the seventy participating players were student-athletes of color. Also, top recruits generally have multiple offers, and less-recruited high school football players might attend any college football program that offered a scholarship, regardless of coaching diversity. 


\section{Graduate Assistants}

As mentioned, becoming a GA or QC has become a hiring standard that precedes promotions to full-time coaching positions. GAs are similar to the student-athletes, in that they receive athletic aid for academic programs, and receive stipends for living expenses (Daughters, 2012). However, GAs are not included in the Annual Progress Report (APR) that holds college football programs accountable for their student-athletes graduation rates. The work is often exhaustive with a workload sometimes accruing 100 hours a week (Leonard, 2012). Individuals are limited by the NCAA to three years of participation in the GA program. In August of 2012, the NCAA increased the number of GAs from two to four in an attempt to increase minority coaches (FootballScoop, 2012), but the increase of GAs without a diversity plan could potentially increase the diversity deficit. Coach 13 (a nonwhite coach at a major FBS football program) stated:

Without actual hiring requirements attached to this policy, it will not accomplish its goal. Head coaches bring on who they know. The NCAA may say it increased GAs to increase the number of minority coaches, but that is not the agenda of college football programs.

\section{Quality Control Assistants and Restricted Earnings Coaches}

Lower revenue programs concerned about maintaining a level playing field with high revenue programs have scrutinized the QC position, because the position was meant to be a non-coaching position (Birkett, 2010). Division I college football programs are limited to ten full-time coaching positions, and now four GA positions. The limitations are set to maintain a level playing field, so that college football programs with more money cannot secure an unfair advantage by hiring more coaches than smaller programs. The job description for QCs often includes video editing, statistic and video analysis, and administrative paperwork. The de facto role, however, has predominantly been a coaching role, and this position has been used by a number of programs to circumvent the coaching limitations set by the NCAA (Birkett, 2010). Perhaps in an attempt to untangle itself from the regulatory process of this position, the NCAA has not only allowed for the unlimited number of QCs per program, it has deregulated the recruiting roles this position has been restricted to in the past. That is, GA and QC positions can now participate in the recruiting of high school and junior college studentathletes. This policy has the opportunity to create a pipeline for nonwhites aspiring to become full-time coaches in college football programs.

QC positions have been used to staff more coaches at one-fifth the salary of the lowest paid assistant coaches. Coach 11 (a nonwhite QC at another major FBS school) said, "The 
trend is to move as many low cost coaches into the QC positions to provide more coaches and larger recruiting staffs ... a trend that will create un-level playing fields and benefit schools that can afford hiring more QCs and restricted earnings coaches." This particular coach had personally benefited from the increase in QC positions, since he had just been hired onto a Division I program from a Division II program. This move from a lower-level football program to the FBS division represents a significant increase in future earning potential. Coach 14 (nonwhite QC from a separate FBS football program) explained that:

The benefit of the QC position over a GA position is that you get paid more, and you do not have to go to school. Otherwise the positions only vary by what the head coach thinks you can handle. QCs are not supposed to coach, but they are all coaching positions. The deregulation has allowed for GAs and QCs to take on more recruiting responsibility. I have not seen how either position is being used to increase the number of minority coaches.

The fact that the NCAA has deregulated recruiting restrictions for GAs and QCs is significant because it indicates that they have acknowledged the role of these positions as coaches and recruiters. Since the number of college coaching positions is limited to twelve per program, and the number of GAs is limited to four, many college football programs pack as many QCs and restricted earnings coaches as it can afford to help offset its coaching limitations. In this way, the QC position could provide more opportunities for nonwhite coaches because their numbers are not limited. To understand the impact of the QC and restricted earnings position on the diversity deficit, the NCAA and other reporting agencies must report the demographic data of these entry-level positions. If not, these potential pipelines will only widen the diversity deficit, and college gyms and gridirons will continue to characterize players as non-paid alienated labor who enrich the highly paid slave masters depicted by white college coaches.

\section{College Football Coaches and Participants}

Of the seventeen participants, three were head coaches, seven were full-time position coaches, one was a GA, three were QCs, two were staff/administrators, one was an athletic director, and all of the full-time coaches have previously served as either a GA, QC or restricted earnings coach. All but one were male, six were white, and the other eleven participants were nonwhite. Due to the small number of nonwhite college coaches who did not identify as either black or white, disaggregating the racial identifiers in any more detail would place these coaches at risk of losing anonymity.

The following synoptic table represents the data collected from the college coaches. 
The original data had eleven identifying markers and independent control variables (e.g., gender, years of experience, etc.). Identifying markers that might jeopardize the anonymity of the participants were excluded from the synoptic table. The other variables are themes that I found within the transcriptions. In general, the white coaches and the coaches of color talked very differently about race and the coaching pipeline. The white coaches spoke in terms of a colorblind world and meritocracy, whereas most of the coaches of color commented on "good ol' boy" networks (or hiring trees), lack of coaches of color in leadership positions, racism/ stereotypes, tokenism and failure of the GA position to diversify college football.

Table 1: Synoptic table of interviews with college coaches.

\begin{tabular}{|c|c|c|c|c|c|c|c|c|c|c|}
\hline Pseudonym & Position & White & $\begin{array}{l}\text { Non- } \\
\text { white }\end{array}$ & Colorblind & Meritocracy & $\begin{array}{c}\text { Good Ol' } \\
\text { Boy } \\
\text { Networks }\end{array}$ & $\begin{array}{c}\text { Racism/ } \\
\text { Stereotypes }\end{array}$ & Tokenism & $\begin{array}{c}\text { Not enough } \\
\text { coaches of } \\
\text { color in } \\
\text { leadership } \\
\text { positions }\end{array}$ & $\begin{array}{c}\text { GA is not } \\
\text { diversifying } \\
\text { college } \\
\text { football }\end{array}$ \\
\hline Coach 3 & $\mathrm{HC}$ & $\mathrm{x}$ & & $\mathrm{x}$ & $\mathrm{x}$ & & & & & \\
\hline Coach 5 & $\mathrm{HC}$ & $x$ & & $\mathrm{x}$ & $\mathrm{x}$ & & & & & \\
\hline Coach 7 & $\mathrm{HC}$ & $\mathrm{x}$ & & $x$ & $x$ & & & & & \\
\hline Coach 2 & $\begin{array}{c}\text { Assistant } \\
\text { HC }\end{array}$ & $\mathrm{x}$ & & & & & & & $\mathrm{x}$ & $\mathrm{x}$ \\
\hline Coach 8 & $\mathrm{DC}$ & $\mathrm{x}$ & & $x$ & & & & & & \\
\hline Coach 1 & DFO & $\mathrm{x}$ & & $\mathrm{x}$ & & & & & & \\
\hline Coach 17 & $\mathrm{AD}$ & & $\mathrm{x}$ & & & $\mathrm{x}$ & $\mathrm{x}$ & $\mathrm{x}$ & $\mathrm{x}$ & $\mathrm{x}$ \\
\hline Coach 13 & DB & & $\mathrm{x}$ & & & $\mathrm{x}$ & $\mathrm{x}$ & $\mathrm{x}$ & $\mathrm{x}$ & $\mathrm{x}$ \\
\hline Coach 4 & DC & & $\mathrm{x}$ & & & $\mathrm{x}$ & $\mathrm{x}$ & $\mathrm{x}$ & $\mathrm{x}$ & $\mathrm{x}$ \\
\hline Coach 6 & GA & & $\mathrm{x}$ & & & $\mathrm{x}$ & $\mathrm{x}$ & $\mathrm{x}$ & $\mathrm{x}$ & $\mathrm{x}$ \\
\hline Coach 16 & LB & & $\mathrm{x}$ & & & $\mathrm{x}$ & $\mathrm{x}$ & $\mathrm{x}$ & $\mathrm{x}$ & $\mathrm{x}$ \\
\hline Coach 15 & $\begin{array}{c}\text { Player } \\
\text { Personnel } \\
\end{array}$ & & $\mathrm{x}$ & & & $\mathrm{x}$ & $\mathrm{x}$ & $\mathrm{x}$ & $\mathrm{x}$ & $\mathrm{x}$ \\
\hline Coach 10 & $\mathrm{OC}$ & & $\mathrm{x}$ & $\mathrm{x}$ & $\mathrm{x}$ & & & & & \\
\hline Coach 9 & QC & & $\mathrm{x}$ & & & $\mathrm{x}$ & $\mathrm{x}$ & $\mathrm{x}$ & $\mathrm{x}$ & $\mathrm{x}$ \\
\hline Coach 11 & QC & & $\mathrm{x}$ & & & $x$ & $x$ & $x$ & $\mathrm{x}$ & $\mathrm{x}$ \\
\hline Coach 12 & $\begin{array}{l}\text { Restricted } \\
\text { Earnings }\end{array}$ & & $\mathrm{x}$ & & & $\mathrm{x}$ & $\mathrm{x}$ & $\mathrm{x}$ & $\mathrm{x}$ & $\mathrm{x}$ \\
\hline Coach 14 & $\mathrm{QC}$ & & $\mathrm{x}$ & & & $x$ & $\mathrm{x}$ & $\mathrm{x}$ & $\mathrm{x}$ & $\mathrm{x}$ \\
\hline
\end{tabular}

\section{Analysis of Findings}

\section{Colorblindness and Good Ol' Boy Networks}

Five of the six white participants made comments that suggest a colorblind perspective. Many of these comments were in response to the question, "What is hindering the development of coaches of color to full-time coaching positions?" The most basic response was not one of denial, but of complete naivety. Coach 1 illustrates this unawareness with a short and simple statement, "I was not aware that this was an issue."

Colorblindness refuses to acknowledge the well-known use of "good ol' boy" networks. Head coaches and coordinators hire whom they know, and whom they trust. This hiring practice does not require interviews and/or evaluations of lower level coaches for full- 
time positions, nor does it require the head coach to integrate other candidates into the interview process. Coach 9 spent seven years in the QC position and talks about favoritism:

There is a good ol' boy system in place that consists mostly of white Anglo-Saxon males. It is a system that is hard to crack; especially for the position I coach. There are certain positions that are quote "colored coach" positions, if a colored coach is needed to fill a spot. Those football positions are running backs, wide receivers on offense, and defensive line and defensive backs on defense. The offensive line position ... and quarterbacks on offense are good ol' boy positions. Linebackers on defense is usually a good ol' boy position. The good ol' boy system is the main factor.

Meritocracy. A more basic colorblind perspective insists that meritocracy rules, and that race does not matter. Coach 5, a white head coach in college football, believes that a good coach needs only knowledge and experience, but he does not acknowledge the obstacles that exist barring nonwhite coaches from that knowledge and experience:

Good coaches come in all sizes, colors, genders and ages. The only thing hindering any coach, in any sport, is lack of knowledge and/or experience. I've never felt that color, age or gender has had anything to do with anything as far as being able to learn and then teach what you've learned to any athlete.

Although variables of colorblindness and meritocracy are related, I believe one must be differentiated from the other. While colorblindness is the inability or willingness to see race, meritocracy seems to ignore the role it plays in the selection process. Meritocracy ignores the structures and systems in place that prohibit people of color from gaining the same necessary credentials (e.g. knowledge and experience), developing the same resumes, and accumulating the same social capital that provides access to hiring trees. Within the sample population of this research, all four participants who mentioned meritocracy also mentioned qualities of colorblindness. Of the six white participants, five expressed comments that reflect colorblindness, while among the coaches of color, only one (Coach 10) seemed to internalize colorblindness and adopt meritocracy and individualism:

I do not think there is anything hindering the development of coaches of color to fulltime coaching positions. I think there are coaches of color who think because they are minority [they] should be the next guy in line for a full time position coach. In my experience, and this is my experience only, coaches are coaches. If you are a good teacher and are passionate about your job, you will be hired. 


\section{Not Enough Coaches of Color in Leadership Positions}

From the perspective of all nonwhite college coaches that participated, and one white college coach, hiring head coaches of color could have a significant impact on increasing diversity in college coaching. Coach 2, a white assistant head coach stated, "Lack of people of color in enough leadership roles with enough hiring power could be a potential hindrance [to advancing coaches of color to full-time coaching positions]." Coach 4, a nonwhite defensive coordinator at a major D1A program, believed that the whiteness of hiring committees maintains the diversity deficit: "The people making the hiring decisions are mostly Caucasian. [We] need more minority representation in athletic administration \& head coaching positions."

Coach 13, the Director of Player Personel at a major D1A program, believes more black people need to be in administration and on the academic support staff. This staff member said, "There are always going to be black coaches that have played and can relate to the players, but black student-athletes need to see and have interaction with black administrators and black staff members in academic support." Coach 13 expressed that while the current full-time staff is diverse, his view is that the system is not, and that the GA program does not act towards fulfilling diversity agendas. All four of the GA positions at his university are white.

\section{Racism and Stereotypes}

Ten of the eleven coaches of color believed that racism and stereotypes are obstacles to the promotion of nonwhite coaches to full-time coaching positions. None of the six white participants communicated they believed that racism or stereotypes were obstacles to these full-time coaching positions. Coach 9 has been a QC for a major program at a D1A football university for the last seven years, and during our interview reflected on several anecdotes that illustrate how racism and stereotypes hinder Polynesian coaches from being promoted to full-time coaching positions:

Recently, a Polynesian coach got a DUI. Unfortunately, now other Polynesian coaches who are trying to advance get tagged with the stigma of being a drunk wild Polynesian. Whether it's fair or not is irrelevant because it's the truth. Now head coaches have to explain to their AD's when they hire a Polynesian coach how he's different from others. There's also a stereotype that colored coaches are lazy. I think this is only going to change with time. 


\section{Tokenism}

Ten of the eleven coaches of color believe that tokenism plays a part in the hiring of nonwhite coaches, and at the same time, hinders their promotion. None of the white coaches mentioned tokenism during their interviews. Coach 11, a nonwhite QC at a major D1A football program, believes that many coaches of color are simply hired to improve the football program's recruiting of nonwhite student athletes:

I think one of the biggest obstacles of hindering the development of coaches of color is society as a whole. In greater terms this business is still considered a white man's business. More often than not minorities are hired merely for the fact that most kids that play the game of football are minorities, so it is used as a selling point to recruit them and their families.

\section{Summary}

The findings of this study directly addressed the two research questions: 1) What are the experiences of GAs and QCs of color, and how are their entry-level roles and positions interpreted within the professional pipeline of college coaching? 2) What do administrators, staff, full-time college coaches, GAs, QCs and restricted earnings coaches believe is limiting the ability for coaches of color (in entry-level positions) to be promoted to full-time staff positions? The findings indicate that whites generally perceive the diversity deficit from a colorblind perspective and value meritocracy, while nonwhites fault the good ol' boy network, racism and stereotypes. Investigating these research questions allows me to explain some of the issues preventing the matriculation and promotion of coaches of color in the pipeline to full-time coaching positions. Of the white participants that volunteered for the study, three were head coaches, two were coordinators, and one was a staff/administrator.

All but the staff/administrator have carte blanche in the hiring and selection process for full-time coaching positions, and all but one made statements that reflect colorblindness. In contrast, ten of the eleven nonwhite college coaches believe that 1) good ol' boy networks are the major influence within the hiring and selection process, 2) there are not enough head coaches and coordinators of color, 3 ) coaches of color experience racism and stereotyping that hinder their promotion from entry-level positions, 4) coaches of color experience tokenism and are often used for recruiting student-athletes of color, 5) the GA position is not diversifying college football, but 6) the GA and QC positions are appropriate mechanisms for developing coaches of color for full-time positions. In fact, every participant but Coach 2 believed that the GA and QC position are good mechanisms for promoting young coaches to full-time coaching positions. Coach 2 did not say, however, that either the GA or QC position 
was bad, but simply stated, "The GA or QC [position] is always iffy for anyone regardless if they are persons of color. No guarantees."

The high school student-athletes in this study affirm the importance that if competitive programs wish to recruit student-athletes of color, they should hire college football coaches of color. High school student-athletes and their families, however, will have to decide whether the coaches of color that are recruiting them are given roles that have meaningful responsibilities and decision-making power, or whether those coaching positions are being tokenized. Lastly, these families will have to decide whether that reality is important to their college choice.

Limitations. Most likely the greatest limitation of this research project is its sample size. The depth and diversity of participants in this study are significant to considering the sensitive nature of this critical topic. A larger sample size of nonwhite full-time coaches might help us to understand their professional trajectories. By investigating trends and experiences that lead to successful promotion, we might be able to identify roadmaps that can better define policies and programs for linking aspiring coaches of color to the experiences and knowledge development that they need for advancement.

The other major limitation of this study is timing. At this moment three significant court cases are being adjudicated that could potentially impact the environment and experiences of these entry-level positions. The first is the Ed O'Bannon case that claims that the NCAA and their membership institutions have exploited student-athletes and have been allowed to profit from their likeness in perpetuity. The pending court decision will determine whether college student-athletes will remain unpaid amateurs, or become professionalized (Holthaus, 2011; McCann, 2012; PBS, 2011). The second is the court case that currently represents 1900 restricted earnings coaches against the NCAA and its membership institutions for antitrust violations (CBS, 2014). If the courts rule in favor of the plaintiffs, it is likely that the restricted earnings position will disappear. The last case involves the Northwestern University football team's effort to gain membership in the labor union. If this happens, entrylevel college football coaches could benefit from labor representation, and the hiring (or promotion) of candidates to full-time college coaching positions may be held to more equitable hiring standards in the future. Specifically, labor unions could mandate that all fulltime coaching positions be posted publicly and that interviews must include candidates of color; therefore, disrupting the perpetuation of hiring trees and the good ol' boy network. 


\section{Conclusion}

This research establishes that a disconnection exists between white coaches and coaches of color on issues of individualism and meritocracy, and on the challenges of fixing pipeline issues, which I explain as the diversity deficit. First, if whites make up 75\% of college coaches and their views reflect those reported by this study population, then a majority of this fraternity adopts the colorblind perspective and refuses to acknowledge that there is a problem. Second, if a majority of the coaches of color believe that racism, stereotyping and tokenism are indisputable certainties of college football but that their white colleagues are oblivious to it, then this duality of reality within work environments suggests that coaches of color maintain their silence around these issues. Future research should investigate the impact that this disparity has on the well-being of coaches of color. What does it mean to make it into the fraternity of coaching college football, and what are the costs of staying there? How does their silence impact their ability to mentor and lead student-athletes towards self-advocacy, community advocacy or a commitment to social justice?

Tracking the experiences of entry-level positions could provide data for a number of significant studies. For example, reporting agencies currently do not collect information on the graduation rate of GAs. Since these positions are allocated financial resources by the host institution to pay for education, tracking the academic outcomes of GAs simply becomes an obligation of financially-responsible stewards. The Academic Progress Rate (APR) allows the NCAA to issue sanctions against member universities in which athletic programs fall below a $50 \%$ graduation rate. The NCAA and its member universities should consider including GAs in the APR: in this way, these entry-level positions will have a graduate degree to fall back on if they do not receive promotion to full-time college coaching positions. Another possible line of research could study professional or graduate coaching programs and inform institutions regarding whether these programs are more relevant and beneficial to GA coaches and, therefore, a better return on institutional investment. Graduate coaching programs that purposefully expose GAs to the experiences necessary to achieve parity with better-connected applicants could improve the promotion of nonwhite coaches that participate.

Social justice groups and reporting agencies should employ a mixed methods approach of short surveys, in-person interviews, and empirical data gathered by The Institute of Diversity and Ethics in Sports (TIDES). Such an approach to research would collect qualitative and quantitative information regarding the actual experiences of white and nonwhite coaches in college football, while providing a more holistic perspective of diversity. This is important because the TIDES' Hiring Report Card (HRC) does not release diversity data on individual FBS and FCS schools. This information could promote diversity in faculty 
and administrative positions, deter good ol' boy networks in lower-level coaching positions, give high school and community college transfer students diversity information that influences college choice, and apply pressure to institutions that currently contribute to the diversity deficit. Harrison et al. (2009) suggested a Diversity Progress Rate that would measure diversity in athletic leadership positions, and hold individual programs to a standard analogous to the Academic Progress Rate (APR).

Currently the NCAA and the HRC does not measure the demographics of QCs in college football. The reporting and documentation of this information will be important if NCAA member universities are going to continue to use the QC as a coaching and recruiting position. Accordingly, the NCAA and its member universities' participation in collecting this data would recognize and legitimize the position as a pipeline position for nonwhite college football coaches. Collecting this data could indicate whether restrictions are placed on the number of QCs permitted per college football program, and whether the addition of two GA positions this season simply increases the number of white coaches, or whether it contributes to the diversity of college football coaches. It may also be helpful to track the tenure of GA and QC positions to understand if there are any differences within the life cycle of these positions and how they impact promotion to full-time staff positions. This study suggests interesting patterns, but my sample is small, and it also relied mainly on interviews. Therefore, more systematic tracking of coaches' actual experiences would check and expand on my findings and could lead to appropriate interventions.

By examining who is in the GA and QC positions, and what their experiences are, this paper offers suggestions for how these entry-level positions may be used as a point of access for coaches of color. The NCAA and its members have thus far allowed private and state sectors to lead the diversity efforts in college football. If the NCAA and its members can agree that diversity is beneficial to the organization as a whole, and if they participate in the gathering and publication of diversity data membership wide, than paradigmatic change may transform what has become a racial hierarchy in the coaching profession of college football (Huber, Johnson \& Kohli, 2006). A membership-wide collaboration must address its member universities on the four specific areas aforementioned: 1) challenge the neutrality of the NCAA member universities, and the whiteness of the Hiring Search Committees for its college football coaches; 2) validate the experiences and perspectives of college football coaches of color, and understand how these factors affect merit and individual criteria in the hiring process; 3 ) name racist hiring practices, and develop race-conscious hiring policies; and 4) challenge neutrality in policy and identify institutional racism. 
The members of the NCAA are aware that there are three times as many white football coaches as coaches of color, and that these numbers are nearly identical to the percent of white GAs coming through the pipeline, while more than half of their players are nonwhite student-athletes. The NCAA member universities must be challenged to recognize their moral debt, which "reflects the disparity between what we know is right and what we actually do" (Gloria Ladson-Billings, 2006). In this case, the disparity exists between the diversity-laden mission statements of the NCAA member universities and the hiring practices of their athletic coaches, staff and administrators. The NCAA member universities are not innocent bystanders, nor is the organization impotent in its influence over its members. Paolo Freire (1970) put it best when he said, "Washing one's hands of the conflict between the powerful and the powerless means to side with the powerful, not to be neutral."

\section{References}

Anderson, M. L. (2012, July 9). How much do football wins pay off for a college? Freakonomics. Retrieved from http://www.freakonomics.com/2012/07/09/how-muchdo-football-wins-pay-off-for-a-college/

Antonio, A. L. (2002). Faculty of color reconsidered: Reassessing contributions to scholarship. The Journal of Higher Education, September/October, 582-602.

Associated Press. (2014, March 18). Antitrust suit claims NCAA is an "unlawful cartel." Retrieved from http://www.wtsp.com/story/sports/college/2014/03/18/news-sportsncaa/6554627/

Birkett, D. (2010, February 25). Quality-control coaches at the center of NCAA allegations against Michigan football. The Ann Arbor News. Retrieved from http://www.annarbor.com/sports/um-football/quality-control-coaches-at-the-center-ofncaa-allegations-against-michigan-football/

Brooks, D. (2002) African-American Coaches and Their Mobility Patterns in Sport. Paper presented at the Kinesiology Lecture Series at the University of Michigan, Ann Arbor.

Carter, P. (2012). Stubborn roots: Race, culture, and inequality in U.S. and South African schools. Oxford: Oxford University Press.

CBS. (1999, May 9). NCAA To Pay Coaches \$54.5M. Retrieved March 23, 2015, from http://www.cbsnews.com/news/ncaa-to-pay-coaches-545m/

Chang, M. J. (2002). Preservation or transformation: Where's the real educational discourse on diversity? The Review of Higher Education, 25 (2), 125-140. 
Chang, M. (2011). Quality matters: achieving benefits associated with racial diversity. Columbus, OH: The Kirwan Institute for the Study of Race and Ethnicity, The Ohio State University.

Crocker, J. T. (2007). The effects of racism-related stress on the psychological and physiological well-being of non-whites. Rivier Academic Journal, 3 (1), 1-3.

Daughters, A. (2012, March 5). College football: Day in the life of a graduate assistant. Bleacher Report. Retrieved from http://bleacherreport.com/articles/1092264-collegefootball-day-in-the-life-of-a-graduate-assistant

FootballScoop. (2012, April 15). Grad assistants to increase from 2 to 4 in 2012. Retrieved from FootballScoop. http://footballscoop.com/archive-news/grad-assistants-to-increasefrom-2-to-4-in-2012/

Freire, P. (1970). Pedagogy of the oppressed. New York: Herder and Herder.

Gaither, S. (2012, December 28). Hiring of black college football coaches still lagging. Diverse Issues in Higher Education. Retrieved from http://diverseeducation.com/article/50281/

Gillborn, D. (2009). Education policy as an act of white supremacy: Whiteness, critical race theory and education reform. In E. Taylor, D. Gillborn, \& G. Ladson Billings (Eds.), Foundations of critical race theory (pp. 51-72). New York, NY: Routledge.

Hanzus, D. (2013, February 15). Richard Sherman has issues with NFL's Rooney rule. NFL. Retrieved from http://www.nfl.com/news/story/0ap1000000139597/article/richardsherman-has-issues-with-nfls-rooney-rule

Harrison, C. K., Lapchick, R. E., \& Jansen, N. K. (2009). Decision making in hiring: Intercollegiate athletics coaches and staff. New Directions for Institutional Research, 144, 93-101.

Harrison, C.K., \& Yee, S. (2009). Protecting their turf: The head football coach hiring process, and the practices of FBS \& FCS colleges and universities. Indianapolis: Black Coaches and Administrators.

Holthaus, W. (2011). Ed O'bannon v. NCAA: Do former NCAA athletes have a case against the ncaa for its use of their likenesses? Saint Louis University School of Law Journal, 55, 369-394.

Hurtado, S., Milem, J. F., Clayton-Pedersen, A., \& Allen, W. R. (1998). Enhancing campus climates for racial/ethnic diversity through educational policy and practice. Review of Higher Education, 21 (3), 279-302.

Kohli, R., Solórzano, D. (2012). Teachers, please learn our names!: Racial microagressions and the K-12 classroom, Race Ethnicity and Education, 15 (4) 441-462. 
Ladson-Billings, G. (2006). From the achievement gap to the education debt: Understanding achievement in US schools. Educational Researcher, 35 (7), 3-12.

Ladson-Billings G., Tate B. (1995). Toward a critical race theory of education. Teachers College Record, 97, 47-67.

Lapchick, R. L. (2012). Mixed progress throughout collegiate athletic leadership: Assessing diversity among campus and conference leaders for football bowl subdivision (FBS) schools in the 2012-13 academic year. Orlando: The Institute for Diversity and Ethics in Sport, University of Central Florida.

Leonard, T. (2012, August 12). Aztecs grad assistants do football's grunt work. UT San Diego. Retrieved from https://www.utsandiego.com/news/2012/aug/12/aztecs-gradassistants-do-footballs-grunt-work/

Levesque, B. (2009, April 13). Chasing the dream: Life as a graduate assistant. GSHL Football. Retrieved from http://gshlfootball.com/chasing-the-dream-life-as-a-graduateassistant

McCann, M. (2012, September 1). Ed O’Bannon expands NCAA law. Sports Illustrated. Retrieved from http:/www.si.com/more-sports/2012/09/01/obannon-ncaa-lawsuit

Milem, J. F., Chang, M. J., \& Antonio, A. L. (2005). Making diversity work on campus: A research-based perspective. Washington D.C.: American Association of Colleges and Universities.

NCAA. (2012). Race and Gender Demographics Search. Retrieved from http://web1.ncaa.org/rgdSearch/exec/saSearch

Nkomo, S. (1992). The emperor has no clothes: Rewriting "race in organizations." The Academy of Management Review, 17 (3), 487-513.

PBS. (2011). The NCAA lawsuit. Retrieved from

http://www.pbs.org/wgbh/pages/frontline/money-and-march-madness/ncaa-lawsuit/

Pike, J. T. (2011). From the Rooney rule to the Robinson rule: NCAA football and the quest for equal opportunity in head coaching. Widener Journal of Law, Economics and Race, 3 (1), 28-54.

Singer, J. N., Harrison, K., \& Bukstein, S. J. (2010). A critical race analysis of the hiring process for head coaches in NCAA college football. Journal of Intercollegiate Sport, 3 (2), 270-296.

Smith, D.G., Gerbick, G.L., Figueroa, M.A., Watkins, G.H., Levitan, T., Leeshawn, C.M., ... \& Figueroa, B. (1997). Diversity works: The emerging picture of how students benefit. Washington, DC: Association of American Colleges and Universities. 
Reynolds, A. L., Sneva, J. N., \& Beehler, G. P. (2010). The influence of racism-related stress on the academic motivation of black and Latino/a students. The Journal of College Student Development, 51 (2), 135-149.

Solorzano, D. (1998). Critical race theory, racial and gender microaggressions, and the experiences of Chicana and Chicano scholars. International Journal of Qualitative Studies in Education, 11, 121-136.

Solorzano, D., Ceja, M. \& Yosso, T. (2000). Critical race theory, racial microaggressions and campus racial climate: The experiences of African American college students. Journal of Negro Education, 69, 60-73.

Ullucci, K., \& Battey, D. (2011). Exposing color blindness/grounding color consciousness: Challenges for teacher education. Urban Education, 46 (6), 1195-1225.

Yosso, T.J. (2005). Whose culture has capital?: A critical race theory discussion of community cultural wealth. Race, Ethnicity and Education, 8 (1), 69-91. 